\title{
Relation between Leadership Styles and Behaviors of Nurse Managers' and Organizational Commitment of Staff Nurses
}

\author{
Hend Mohamed Ali ${ }^{1}$; Sahar Ahmed Abood ${ }^{2}$; Mona Thabet Abd el-baset ${ }^{3}$
}

\author{
1-Bachelor of Nursing, Faculty of Nursing, Minia University, \\ 2- Professor of Nursing Administration, Faculty of Nursing, Minia University. \\ 3- Lecturer of Nursing Administration Department, Faculty of Nursing, Minia University
}

\begin{abstract}
Background: the quality of relationship between supervisors and subordinates and leadership of head nurses played an important role in their subordinates such as organizational commitment, job performance and promotions. Aim: the aim of this study was to determine relation between leadership styles and behaviors of nurse managers' and organizational commitment of staff nurses. Design: Descriptive correlational research design was used to achieve the aim of the current study. Setting: the study was conducted in Health Insurance Hospital, Minia governorate at Minia city. Subjects: the subject of study was included all nurse managers (head nurses) and staff nurses in Health Insurance Hospital $(\mathrm{n}=255)$, divided as (17 nurse managers +238 staff nurses). Tools: three tools were used to collect data pertinent to the study as: Leadership Styles Questionnaire (Multifactor Leadership Questionnaire 5X), Leadership Behavior, and the Organizational Commitment of the Staff Nurses Questionnaire. Results: The study revealed that highest percentage of head nurses had high level for transformational $(63 \%)$ and transactional style $(59.7 \%)$; also, more than half $(58.8 \%)$ of head nurses had high level of leadership behaviors and more than one third (39.9\%) had moderate level. Moreover, it was noted that more than half (57.1\%) had high level commitment, and more than one third (41.2\%) had moderate level. Conclusion: there were positive correlations between leadership style as well as leadership behaviors with the organizational commitment. Recommendations: Periodic training courses should be provided in order to keep head nurses updating knowledge, skills, and attitudes regarding to leadership skill, behaviors and styles.
\end{abstract}

Keywords: leadership behaviors, leadership style, organizational commitment, staff nurse, nurse manager

\section{Introduction}

The complex and multi-faceted nature of modern healthcare requires nursing leadership professionals who can create effective intra-departmental and facility-wide systems of healthcare delivery, while leading a productive and efficient workforce. This allows for optimal patient care in any medical setting, from private hospitals and clinics to large medical centers and veteran's administration hospitals. Nursing administration is a broad term that encompasses nursing professionals who are knowledgeable of leadership practices as they relate to the nursing profession (1).

Moreover, nursing manager and administrators have the responsibility to implement all of the nursing procedures in a healthcare environment. While administrators can communicate with patients, they will be more than likely manage a team of nurses who will work on the front lines interacting with the patients who are seen in the facility. As a managerial team member in the nursing department, and administrator, head nurse should ensure that the department is complying with laws and that the department is fully staffed (2).

Therefore, the most significant managerial function needed is leadership the dynamic force that stimulates, motivates and coordinates an organization. Leadership consists of interpersonal influence, exercised in a situation and directed by means of the communication process, toward the attainment of specific goals; it involves attempts by one person to affect the behavior of others in a situation (3).

Leadership, since its appearance in literature in the 19th century, has been attributed to quality in education, research and management (4). The central theme of leadership in health care revolves around the effectiveness of leadership in the improvement of the quality of care, client satisfaction, patient outcomes and financial performance (5). Nursing requires leaders who are highly creative in their thinking, to be able to piece together multiple pieces of seemingly

$P$ a g e | 54 unrelated information, and test out new approaches in the pursuit of new meaning in support of nursing patient care. It will no longer be about the "nursing leader"; rather it will be about nursing leaders working with other health-related leaders and consumers $(6,7)$.

Leadership as a management function is mostly related to human resources and social interaction. It is the process of influencing a group of people towards achieving organizational goals (8). Leadership is the ability of a manager to influence, motivate, and enable employees to contribute toward organizational success (9).

Nurse managers as first-line leaders (head nurses) have a responsibility to induce changes in the clinical environment. Recently, this responsibility of nurse managers has become more important than ever due to demands for rationalization, cost cuttings, advancements in medical technology, and reduced lengths of hospital stay (10). Moreover, managers can utilize various leadership styles to lead and direct their employees including autocratic, bureaucratic, laissez-faire, charismatic, democratic, participative, transactional, and transformational leadership styles. There is no universal leadership style different leadership styles are needed for different situations. Effective leader must know when to exhibit a particular approach (11).

Furthermore, the efficient use of leadership styles is an essential ingredient of good leadership skills. Leadership styles are the various combinations of tasks and behaviors which motivate people towards the achievement of set goals. A critical leadership skill is the use of different leadership styles (12). Leadership styles are a combination of tasks and transaction behaviors that influence people in achieving goals (13).

For the past three decades, a pair of predominant leadership styles (transactional and transformational leadership) has received a significant amount of attention. Transformational leadership is a process in which "leaders and

Hend M., et al 
followers raise one another to higher levels of motivation and morality" (14). By implementing transformational leadership styles, subordinates feel empowered leading to organizational commitment and solving the employee morale problems which in turn lead to job satisfaction (15).

Transactional leadership starts with the idea that employees agree to obey their leader totally when they accept a job. The "transaction" is usually the organization paying the team members in return for their effort and compliance. The leader has a right to "punish". The leader could give team members some control of their income/reward by using incentives that encourage even higher standards or greater productivity. Alternatively, a transactional leader could practice "management by exception" - rather than rewarding better work, the leader could take corrective action if the required standards are not met (16).

The laissez-faire leadership style is also known as the "hands-off" style. It is one in which the manager provides little or no direction and gives employees as much freedom as possible. All authority or power is given to the employees and they must determine goals, make decisions, and resolve problems on their own (17).

So the efficient use of leadership styles is an essential ingredient of good leadership skills. Leadership styles are the various combinations of tasks and behaviors which motivate people towards the achievement of set goals. A critical leadership skill is the use of different leadership styles. Leadership styles are a combination of tasks and transaction behaviors that influence people in achieving goals (18).

The success or failure of proper organizations, nations and other social units has been largely credited to the nature of their leaders and manager leadership style (19). Moreover, as explained in manufacturing companies, leadership is really a process for impacting on others commitment toward recognizing their full potential in achieving goals, vision with passion and integrity (20).

Organizational commitment is a common phenomenon which has been extensively addressed by many researchers worldwide due to its importance to the organization (21). In the meantime, over the past two decades, organizational commitment was the dominant job attitude that has been the center of researchers' attention (22). Today, healthcare organizations are challenged by the lack of commitment from nurses and doctors due to their choices to leave the organization (23).

Commitment is defined as the psychological bond that is characterized by the members' feeling of attachment, obligation, and loyalty to a given organization. Commitment also describes the level of employees' acceptance of the organization's goals and the willingness they have to work towards these goals $(23,24)$.

Organizational commitment shows the psychological attachment of an employee to the organization (25). According to Meyer and colleagues (2002) there are three types of organizational commitment: affective, continuance and normative commitment. Affective commitment relates to an employee's emotional attachment to the organization and its goals. Continuance commitment shows cognitive attachment between an employee and his or her organization because of the costs associated with leaving the organization. Finally, normative commitment refers to typical feelings of obligation to remain with an organization (26).

Thus, leadership of managers plays a critical role in employees 'job satisfaction and commitment $(27,28)$. The achievement of organizational goals largely depends on managers and their leadership behavior and styles. The use of a particular leadership behavior by manager affects both job satisfaction and productivity and commitment of the employees (29).

\section{Significance of the study}

Manger function as a leader and act on cement commitment of staff in the future, nurses' manger can set an example by personally welcoming whoever walks through the door or asks about joining the organization or initiative. Ask questions and get nurses know, and make them feel valued. That not only gives people a good feeling about the effort and encourages them to become involved, but it also provides the basis for developing a relationship that helps nurse manger function as a leader and acts to cement commitment in the future (30).

Nurses today work in an environment that overflows with unique challenges and opportunities, yet they tend to be over-controlled but grossly uninspired. There is an increasing need for leadership that inspires followers to aspire for a common greater good in a supportive environment is provided by leadership style (31). The role of leadership is to ultimately accomplish outcomes for organizations through influencing others (31).

Moreover, during my work in Health Insurance Hospital, it was observed that some nurses in hospital have negative commitment to their units, and desires to leave work. And by the speaking with nurses, they expressed the negative feeling from their manger; due to their manger leadership style, and behaviors when deal with them. Thus, it is crucial to determine the relation between leadership styles and behaviors of nurse managers which can play an instrumental role in promoting organizational commitment of nurses working in health care settings.

\section{Aim of the study}

The aim of the current study is to investigate or to determine relation between leadership styles and behaviors of nurse managers and organizational commitment of staff nurses

\section{Research questions}

- Is there a relation between leadership styles of nurse managers and organizational commitment of staff nurses?

- Is there a relation between leadership behaviors of nurse managers and organizational commitment of staff nurses?

- Is there a relation between leadership behaviors and leadership styles among head nurses?

\section{Subjects and methods \\ Research design:}

Descriptive correlational research design was used to achieve the aim of the current study.

\section{Setting:}

The study was conducted in Health Insurance Hospital Minia governorate.

\section{Subjects:}

Study subject was included all nurse managers (head nurses) and staff nurses in Health Insurance Hospital 
departments $(\mathrm{n}=255)$, divided as $(17$ nurse managers +238 staff nurses)

\section{Data collection tools:}

Data was collected by using three tools as follows:

Tool (I): Leadership Styles Questionnaire, it was included two parts as follows:

Part 1: Demographic data sheet which was attached with tools to get information among nurse mangers. It was included: gender, age, residences, years of experience, years of experience in current department, unit, and head nurse code.

Part 2: Multifactor Leadership Questionnaire 5X:

This tool developed by Bass \& Avolio (2004) ${ }^{(32)}$ and was adopted to measure the nurse managers' leadership styles and translated into Arabic. It was consisting of transformational, transactional, and laissez-faire leadership styles with nine subscales as: five subscales for transformational (Idealized Influence (attribute), Idealized Influence (behavior), Inspirational Motivation, Intellectual Stimulation, and Individualized Consideration), three subscales for transactional (Contingent Reward, Managementby-Exception- active, and Management-by-Exceptionpassive) and one Laissez Faire.

Participants were asked to judge the extent to which they view their head nurses engaged in specific behaviors measured by the MLQ. The MLQ Form 5X is self-scoring and used 27 items to measure the nine subscales (3 items for each). The items was rated using a 5-point Likert scale labeled as $(0=$ not at all, $1=$ once in a while, $2=$ sometimes, 3 = fairly often, 4 = frequently, if not always). The scoring system was calculated according to the sum of each style items. High score was showing high effectiveness of leadership style perception while low score was implying low effectiveness perception in the scale.

\section{Tool (II) - Leadership Behavior}

This tool developed by Strange \& Mumford (2002)

(33) and was adopted by the researcher to assess nurse manager's leadership behaviors, and translated into Arabic. It includes 26 items divided to 4 domains as follows: leader's encouragement and support to subordinates (13 items); leader's clarification of vision to his/her subordinates ( 8 items); consistency of leader's behavior with his/her vision ( 5 items); and leader's persuasiveness in convincing subordinates to accept his/her vision (4 items). Each items was measured using five-point Likert scale $(1=$ strongly disagree, $2=$ disagree, 3 = neutral, $4=$ agree, and 5= strongly agree).

The scoring system was according to the higher score of leaders' behaviors domain. The higher score of behavioral domain items indicated high level of behavior and low score indicated low level on behavioral domain.

Tool (III) - The Organizational Commitment of the Staff Nurses Questionnaire, it was included two parts as follows:

Part 1: Demographic data sheet was attached with tool to get information among staff nurses. It was included: gender, age, residences, years of experience, years of experience in current department, certificate, and unit.

Part 2: The Organizational Commitment of the Staff Nurses scale

This tool developed by Meyer et al. (1993) ${ }^{(34)}$ and was adopted by the researcher to assess organizational commitment of staff nurse. It included 18 items divided to 3 factors of organizational commitment (affective, continuance, and normative). Each factor included 6 items and was measured using five-point Likert scale $(1=$ strongly disagree, $2=$ disagree $3=$ neutral, $4=$ agree, $5=$ strongly agree). Four items are negatively worded. The scoring system was ranged from 18 to 90, the higher score indicates higher level staff nurses commitment to the organization and low score indicates low commitment.

\section{Validity of the tools:}

Tools were tested for the content validity by a jury of 5 experts in the field of Nursing Administration and a necessary modification was done. The jury composed of two Assistant Professors from Faculty of Nursing, Minia University and three Assistant Professors from Faculty of Nursing, Assuit University. Each of the expert panel was asked to examine the instrument for content coverage, clarity, wording, length, format and overall appearance.

\section{Reliability of the tools}

Reliability of the tools was performed to confirm consistency of tools. The internal consistency measured to identify the extent to which the items of the tools measure the same concept and correlate with each other by Cronbach's alpha test; the reliability of the tools were leadership styles $(\alpha=0.889)$, leadership behavior $(\alpha=0.874)$, and organizational commitment ( $\alpha=0.791)$.

\section{Pilot study:}

A pilot study was conducted on $10 \%$ of participants as (2) of head nurse and (24) of staff nurse to ascertain the clarity, comprehensiveness and applicability of the tools as well as to estimate the appropriate time required to fill the questionnaire. Based on pilot study there was no modification done, and it was added to final results.

\section{Study procedure:}

- Written approvals were obtained from administrative authorities (Faculty dean, Vice dean for teaching and student affairs, Director of Health Insurance Hospital, Nursing Director of Health Insurance Hospital, and head of departments of the Health Insurance Hospital) after explaining the purpose of the study.

- The questionnaires were distributed to all the participants after explaining the purpose and process of data collection. Questionnaires were directly administered and supervised by the researcher with the assistance of head nurse for each department.

- Participants were given from 15 minute to 30 minute to answer the questionnaires. They were allowed to discuss with researcher any item that needs more clarification.

- The data collection was performed all head nurses and staff nurses of health insurance hospital during the period of 6 months from the beginning of September 2018 to February 2019.

\section{Ethical consideration:}

a) An oral consent was obtained from participants to collect the study data before data collection. After explanation of the purpose of the study, the privacy 
and confidentiality of the answers were guaranteed by the researcher.

b) Each assessment sheet was coded and participants' names not appeared on the sheets for the purpose of anonymity and confidentiality.

c) The participants were informed that their participation in the study was completely voluntary and there was no harm if they not participate in the study.

\section{Statistical analysis:}

Data entry was done using compatible personal computer. Statistical analysis done by using statistical package of social science (SPSS) version 25 and excel for figures. The content of each tool was analyzed, categorized and then coded. Data were presented using descriptive statistics in the form of frequencies and percentages for qualitative variables, and means and standard deviations for quantitative variables. Statistical significance used at $\mathrm{P}$ value $<0.05$.

\section{Results:}

Table (1) Distribution of the personal data regarding to head nurses and staff nurses

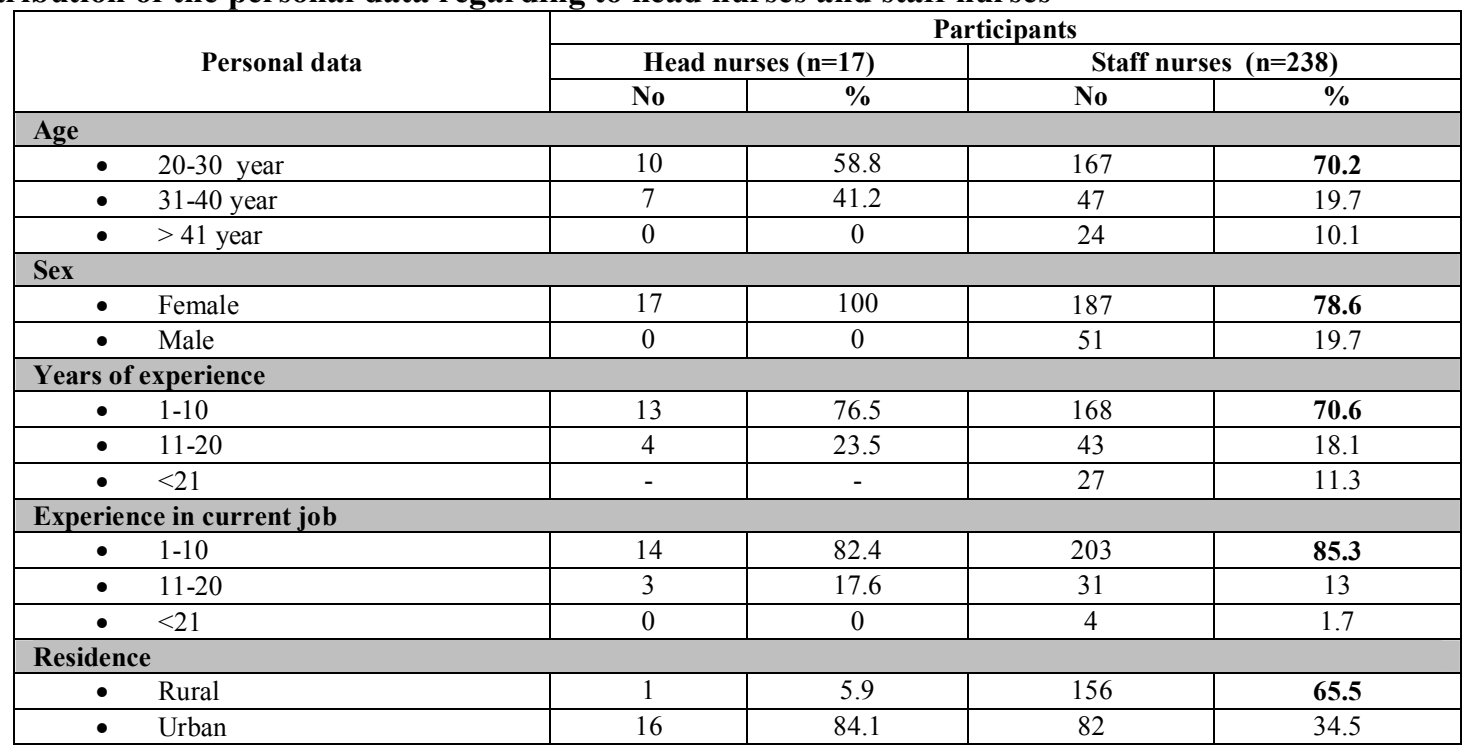

Table (1): shows that more than half (58.8\%) of head nurses age ranged from (20-30) years old. In relation to gender, all of them $(100 \%)$ were females. Concerning to years of experience, more than three quarter $(76.5 \%)$ had (1-10) years of experience; in relation to years of experience in the current job the majority of them (82.4\%) had (1-10) years of experience. As regard to residence, the majority of them $(84.1 \%)$ lived in urban areas.

Regarding personal data of staff nurses shows that less than three quarter $(70.2 \%)$ of staff nurses age ranged from (20-30) years old with mean age $(28.6+7.03)$. In relation to gender, more than three quarter of them $(78.6 \%)$ were females. Concerning to years of experience, more than two third (70.6\%) had (1-10) experience years, and in relation to years of experience in the current job the majority of the sample (85.3\%) had (1-10) experience years. As regard to residence, about two third of them (65.5\%) were lived in rural areas.

Table (2) Frequency distribution by percentage of staff nurses perception regarding their head nurses leadership style

\begin{tabular}{|c|c|c|c|c|c|c|}
\hline \multirow{3}{*}{ Leadership styles } & \multicolumn{6}{|c|}{$\begin{array}{l}\text { Staff nurses perception regarding their head nurses leadership style } \\
(\mathbf{N}=\mathbf{2 3 8})\end{array}$} \\
\hline & \multicolumn{2}{|c|}{ Low } & \multicolumn{2}{|c|}{ Moderate } & \multicolumn{2}{|c|}{ High } \\
\hline & $\mathbf{N}$ & $\%$ & $\mathbf{N}$ & $\%$ & $\mathbf{N}$ & $\%$ \\
\hline - Idealized Influence (attribute) & 26 & 10.9 & 71 & 29.8 & 141 & 59.2 \\
\hline - Idealized Influence (behavior) & 19 & 8 & 66 & 27.7 & 153 & 64.3 \\
\hline - Inspirational Motivation & 7 & 2.9 & 79 & 33.2 & 152 & 63.9 \\
\hline - Intellectual Stimulation & 9 & 3.8 & 80 & 33.6 & 149 & 62.6 \\
\hline - Individualized consideration & 11 & 4.6 & 76 & 31.9 & 151 & 63.4 \\
\hline Transformational leadership style & 3 & 1.33 & 85 & 35.7 & 150 & 63 \\
\hline - Contingent reward & 7 & 2.9 & 86 & 36.1 & 145 & 60.9 \\
\hline - Management-by-Exception- active & 7 & 2.9 & 59 & 24.8 & 172 & 72.3 \\
\hline - Management-by-Exception- passive & 66 & 27.7 & 37 & 15.5 & 135 & 56.7 \\
\hline Transactional leadership style & 4 & 1.7 & 92 & 38.7 & 142 & 59.7 \\
\hline Lassie fair-style & 201 & 84.5 & 18 & 7.6 & 19 & 8 \\
\hline
\end{tabular}

Table (2) shows that highest percentage of the staff nurses perceived their head nurses had high level for transformational leadership style (63\%) and its subscales $(59.2 \%, 64.3 \%, 63.9 \%, 62.6 \%$, and $63.4 \%$ respectively) as well as had high level for transactional leadership style $(59.7 \%)$ and its subscales $(60.9 \%, 72.3 \%$, and $56.7 \%$ respectively); except the majority of the staff nurses perceived their head nurses had low level to lassie faire style $(84.5 \%)$. 
Minia Scientific Nursing Journal (Print) (ISSN 2537-012X) Vol. (7) No. (1) June 2020

Table (3) Frequency distribution by percentage of head nurses perception regarding their leadership behavior

\begin{tabular}{|c|c|c|c|c|c|c|}
\hline \multirow{3}{*}{ Leadership behavior dimensions } & \multicolumn{6}{|c|}{ Head nurses leadership behavior $(\mathrm{N}=17)$} \\
\hline & \multicolumn{2}{|c|}{ Low } & \multicolumn{2}{|c|}{ Moderate } & \multicolumn{2}{|c|}{ High } \\
\hline & $\mathbf{N}$ & $\%$ & $\mathbf{N}$ & $\%$ & $\mathbf{N}$ & $\%$ \\
\hline Leader's encouragement and supportive to subordinates & 4 & 1.7 & 92 & 38.7 & 142 & 59.7 \\
\hline Leader giving subordinate her/his clear vision & 49 & 20.7 & 52 & 21.9 & 136 & 57.4 \\
\hline Leader's behavior is consistent with her/his vision & 10 & 4.2 & 46 & 19.3 & 182 & 76.5 \\
\hline $\begin{array}{l}\text { Leader is persuasive in convincing subordinates to } \\
\text { acknowledging her/his vision }\end{array}$ & 51 & 21.4 & 47 & 19.7 & 140 & $\mathbf{5 8 . 8}$ \\
\hline Total of leadership behavior & 3 & 1.3 & 95 & 39.9 & 140 & 58.8 \\
\hline
\end{tabular}

Table (3) shows that the highest percentage staff nurses perceived their head nurses had high level to all dimensions of leadership behaviors $(59.7 \%, 57.4 \%, 76.5$, and 58.8\% respectively). Regarding total score of leadership behaviors, it was noted that more than half $(58.8 \%)$ of staff nurses perceived their head nurses had high level of leadership behaviors and more than one third $(39.9 \%)$ had moderate level.

Table (4) analysis of variance among head nurses and staff nurses regarding to leadership styles and leadership behaviors dimensions $(\mathbf{n}=\mathbf{2 5 5})$

\begin{tabular}{|c|c|c|c|c|}
\hline \multirow[t]{2}{*}{ Variables } & $\begin{array}{c}\text { Staff nurses } \\
\mathbf{N}=\mathbf{2 3 8}\end{array}$ & $\begin{array}{c}\text { Head nurses } \\
\mathrm{N}=17\end{array}$ & \multirow[t]{2}{*}{ Z-test } & \multirow[t]{2}{*}{$\mathbf{P}$} \\
\hline & Mean + SD & Mean+ SD & & \\
\hline Transformational leadership & $41.8 \pm 1.07$ & $43.8 \pm \overline{7} .64$ & 0.751 & 0.454 \\
\hline Transactional leadership style & $24.3 \pm 7.20$ & $26.2+4.52$ & 1.06 & 0.290 \\
\hline Lassie-faire & $2.12+2.80$ & $1.41 \pm 1.97$ & 1.02 & 0.308 \\
\hline Leadership behaviors & $102.4 \pm 14.4$ & $96.3+20.7$ & 1.20 & 0.321 \\
\hline
\end{tabular}

Table (4) shows that there are no statistical significance differences between head nurses perception to themselves about leadership styles and leadership behaviors; and staff nurses perception about their head nurses leadership styles and behaviors.

Table (5) Frequency distribution by percentage of staff nurses perception regarding organization commitment and its dimension

\begin{tabular}{|c|c|c|c|c|c|c|}
\hline \multirow{3}{*}{ Organization commitment } & \multicolumn{6}{|c|}{ Staff nurses commitment perception $(\mathrm{N}=\mathbf{2 3 8})$} \\
\hline & \multicolumn{2}{|c|}{ Low } & \multicolumn{2}{|c|}{ Moderate } & \multicolumn{2}{|c|}{ High } \\
\hline & $\mathbf{N}$ & $\%$ & $\mathbf{N}$ & $\%$ & $\mathbf{N}$ & $\%$ \\
\hline - $\quad$ Affective Commitment & 10 & 4.2 & 116 & 48.7 & 112 & 47.1 \\
\hline - $\quad$ Continuance Commitment & 8 & 3.4 & 62 & 26.1 & 168 & $\overline{70.6}$ \\
\hline - $\quad$ Normative Commitment & 5 & 2.1 & 66 & 27.7 & 167 & 70.2 \\
\hline Total organizational commitment & 4 & 1.7 & 98 & 41.2 & 136 & 57.1 \\
\hline
\end{tabular}

Table (5) shows that the near the half (48.7\%) of staff nurses had moderate level regarding affective commitment; while more than two third (70.6\%, and $70.2 \%$ ) had high level regarding continuance commitment and normative commitment. Regarding the total score of organizational commitment, it was noted that more than half $(57.1 \%)$ had high level commitment and more than one third had (41.2\%) moderate level

Table (6) correlations between leadership styles, leadership behavior and organizational commitment

\begin{tabular}{|c|c|c|c|c|c|c|}
\hline \multicolumn{2}{|l|}{ Variable } & $\begin{array}{l}\text { Transformational } \\
\text { leadership }\end{array}$ & $\begin{array}{l}\text { Transactional } \\
\text { leadership }\end{array}$ & $\begin{array}{l}\text { Lassie- } \\
\text { fair }\end{array}$ & $\begin{array}{l}\text { Leader } \\
\text { behavior }\end{array}$ & $\begin{array}{l}\text { organizational } \\
\text { Commitment }\end{array}$ \\
\hline $\begin{array}{l}\text { Transformational } \\
\text { leadership }\end{array}$ & $\begin{array}{l}\mathbf{R} \\
\mathbf{P}\end{array}$ & 1 & $\begin{array}{l}0.921 * * \\
0.000\end{array}$ & $\begin{array}{l}.051- \\
0.435\end{array}$ & $\begin{array}{l}0.672 * * \\
0.000\end{array}$ & $\begin{array}{l}\mathbf{0 . 3 0 2} * * \\
\mathbf{0 . 0 0 0}\end{array}$ \\
\hline $\begin{array}{l}\text { Transactional } \\
\text { leadership }\end{array}$ & $\begin{array}{l}\mathbf{R} \\
\mathbf{P}\end{array}$ & - & 1 & $\begin{array}{l}0.53 \\
0.418 \\
\end{array}$ & $\begin{array}{l}0.666 * * \\
0.000\end{array}$ & $\begin{array}{l}0.529 * * \\
0.000\end{array}$ \\
\hline Lassie=fair & $\begin{array}{l}\mathbf{R} \\
\mathbf{P} \\
\end{array}$ & - & - & 1 & $\begin{array}{l}0.008- \\
0.903 \\
\end{array}$ & $\begin{array}{l}0.067- \\
0.304 \\
\end{array}$ \\
\hline Leaders behavior & $\begin{array}{l}\mathbf{R} \\
\mathbf{P}\end{array}$ & - & - & - & 1 & $\begin{array}{l}.375^{* *} \\
.000\end{array}$ \\
\hline Commitment & $\begin{array}{l}\mathbf{R} \\
\mathbf{P}\end{array}$ & - & - & - & - & 1 \\
\hline
\end{tabular}

Table (6) there are positive correlations between transformational with transactional $(\mathrm{r}=0.922, \mathrm{p}=0.00)$; with leadership behavior $(\mathrm{r}=0.672, \mathrm{p}=0.000)$ and with organizational commitment $(\mathrm{r}=0.302, \mathrm{p}=0.000)$; also, there are positive correlations between transactional leadership style with leadership behavior $(\mathrm{r}=0.666, \mathrm{p}=0.000)$ and with organizational commitment $(\mathrm{r}=0.529$, $\mathrm{p}=0.000)$; while no correlation between lassie-faire style and other styles as well as leadership behavior and organizational commitment.

\section{Discussion:}

Nurses working in any healthcare sector represent the most viable asset that contributes to building a reputation for health institutions and the abundance and flow for patients seeking better health services, but the behaviors of nurses toward organizations as satisfaction, commitment, and decision to stay or to leave the institutions may or may not be affected by organizational design dimensions (structure and culture). The staff nurses may be affected by their managers as head nurses skills and behaviors such as conflict management skills, decision making skills and styles, motivation and leadership style and behaviors (31-32).

Also, organizational commitment is an important management element that determines nurses' work performance, productivity, and impact of organizational effectiveness (33-35). Thus, the quality of relationship between supervisors and subordinates has been considered as fundamental to employees' behavior; as well the leadership of managers as head nurses played an important role in several work outcomes of their subordinates such as organizational commitment, job performance and promotions (36). 
Regarding personal data of head nurse; the current study displayed that more than half of head nurses age ranged from (20-30) years old. In relation to gender, all of them were females. Concerning to years of experience, more than three quarter had (1-10) years of experience; in relation to years of experience in the current job the majority of them had (1-10) years of experience. As regard to residence, the majority of them lived in urban areas.

Regarding personal data of staff nurses the current study showed that less than three quarter of staff nurses age ranged from (20-30) years old with mean age. In relation to gender, more than three quarter of them was females. Concerning to years of experience, more than two third had (1-10) experience years, and in relation to years of experience in the current job the majority of the sample had (1-10) experience years. As regard to residence, about two third of them were lived in rural areas.

Regarding the leadership style of head nurses as perceived by staff nurses; the current study showed that highest percentage of the staff nurses perceived their head nurses had high level for transformational leadership style $(63 \%)$ and its subscales, as well as had high level for transactional leadership style $(59.7 \%)$ and its subscales; except the majority of the staff nurses perceived their head nurses had low level to lassie-faire style. This result means that the head nurses use the transformational leadership style as the most one followed by the transactional style; and they less use the lassie-faire style.

This may be due to the head nurses' abilities and skill in order to be a good role model; they try to be positive motivators to their staff nurses in order to achieve their unit goals and achieve the optimal nursing care to the patients. As in the transformational head nurse has been motivated followers to perform to their full potential over time by influencing a change in perceptions and by providing a sense of direction'. A transactional head nurse has to be a good leader or manager who functions in a caretaker role and is focused on day-to-day operations'

These results were congruent with Abdelhafiz et al. (2016) ${ }^{(37)}$ who had a study among staff nurses who working in selected hospitals at governmental and private hospital in Jordan; and their findings demonstrated that in all transformational and transactional leadership sub-scales, staff nurses in government hospitals ranked their managers higher than nurse managers in private hospitals, with significant differences observed between the group means

This was also, in same line with Elmezin et al. (2016) (38) who showed in their study that nurses favor transformational leadership over transactional. Nonetheless, neither style is appropriate for inducing nurses' optimal performance, as it lacks the desired leader attributes. Moreover, leader earns the respect and trust of his/her followers, resulting in acceptance of challenging goals. Also, the results of Garg and Ramjee (2013) ${ }^{(39)}$ indicated that leadership in the said Parastatal is more transformational than transactional.

In addition this was in line with this Ahmed et al. (2019) (40) who had a study on staff nurses at Zagazig University Hospitals, Egypt; and their results showed that the majority $(83.9 \%)$ of those studied nurses had a positive perception of transformational leadership behavior and two third $(66.4 \%)$ had a positive perception of transactional leadership behavior.
Also, Majeed et al. (2017) ${ }^{(41)}$ conducted a study to explore relationship between transformational leadership and organizational citizenship behavior, in Malaysia, and they found that nurses had a positive perception about transformational leadership behavior. Also, the results of ElDemerdash and Aldeeb (2016) ${ }^{(42)}$ showed that sixty $(60 \%)$ of head nurses perceived themselves had high transformational leadership style. Aboshaiqah et al. (2014) (43) mentioned that nurses had a perception that their supervisors are more frequently using transformation and transactional than laissez-faire leadership styles

Regarding the leadership behavior, the current study showed that the highest percentage staff nurses perceived their head nurses had high level to all dimensions of leadership behaviors $(59.7 \%, 57.4 \%, 76.5$, and $58.8 \%$ respectively). Regarding total score of leadership behaviors, it was noted that more than half of staff nurses perceived their head nurses had high level of leadership behaviors and more than one third had moderate level.

These results were in same line with Olu-Abiodun and Abiodun (2017) ${ }^{(44)}$ who show the perception of nurses about leadership behavior in their respective hospitals. The average score for the various items under leadership behavior domains ranged between 3.28 and 4.21. The perceptions that 'the leader expresses high performance expectations' (4.21) and 'effective leadership depends on factors that make followers open to the leader and his/her vision' (4.04) had the highest mean scores. The lowest mean score was recorded by the perception that 'followers are devoted and unquestioning of the leader'.

Moreover, in the current study; the highest percentage of leadership dimensions was for Leader's behavior is consistent with her/his vision, followed by leader's encouragement and supportive to subordinates, then leader is persuasive in convincing subordinates to acknowledging her/his vision, and then lowest was leader giving subordinate her/his clear vision

These results were approximately in the line with Olu-Abiodun and Abiodun (2017) ${ }^{(44)}$ in which they revealed that out of the four domains of leadership behavior that were examined, the perception about leader's clarification of vision to his/her subordinates had the lowest mean score $(3.50 \pm$ $0.73)$. Whereas, the perception of leader's encouragement and support to subordinates had the highest mean score $(3.83 \pm$ $0.61)$. The perception about the consistency of leader's behavior with his/her vision had a mean score of $3.81 \pm 0.65$, while, the perception about leader's persuasiveness in convincing subordinates to accept his/her vision had a mean score of $3.74 \pm 0.84$.

This may be due to the transformational style that head nurses use in which they provide more support and guidance to their subordinates, enhance collaboration, make up teams and actively involve others; as well the head nurses may influence their subordinates and increase their engagement by working together to achieve a vision of a preferred future; and this in turn improve their leadership behaviors. This was in line with Lin et al. (2015) ${ }^{(45)}$ who mentioned that the nurse leaders who adopt the transformational leadership style are likely to be providing supervisor support workplace and had more positive leadership behaviors.

The current study showed that near the half of staff nurses had moderate level regarding affective commitment; while more than two third had high level regarding 
continuance commitment and normative commitment; this means that the continuance commitment was the highest one followed by normative and least score was for affective commitment. This result may be due the staff nurses had more fear to leave their job and be unemployed; the increased number of unemployment in Egypt, and the stress and burdens of life.

These results were in line with Dadgar et al. (2013) (46) at Zahedan University of medical sciences found that the highest mean score among participants was in continuance commitment and the lowest was in affective commitment. While Alammar et al. (2016) ${ }^{(47)}$ results were not consistent with these result in which the coefficients were the highest for the affective commitment and this implying that affective commitment is the strongest predictor in their study.

Regarding the total score of organizational commitment in the current study, it was noted that more than half $(57.1 \%)$ had high level commitment, and more than one third $(41.2 \%)$ had moderate level. This mean that the staff nurses had moderate to high level of organizational commitment and this may be due in Egypt once a one had a job in a governmental organization he/she usually remains in it for life because of its benefits, as job security in which he/she not threatening to lose the job, some financial benefits, especially those after retirement.

These study's results agreed with Abed and Elguindy (2014) ${ }^{(48)}$ who found that the mean score of staff nurses' organizational commitment was moderate to high, which was a good score as it indicated that nurses were committed to their hospital and the profession. Also, Lorber and Savic (2014) ${ }^{(49)}$ in Slovenian hospitals found that the level of commitment among staff nurses was high to medium.

These results were in line with Alammar et al. (2016) ${ }^{(46)}$ who had a study about organizational commitment among nurses who working at a large tertiary hospital in Riyadh, Saudi Arabia and their result represented a relatively favorable level of organizational commitment in the participants.

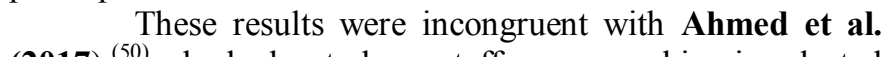
(2017) ${ }^{(50)}$ who had a study on staff nurses working in selected hospital at Beni- Suef city, Egypt; and displayed in their study that the total means score of organizational commitment was moderate, which means that nurses had a moderate level of organizational commitment to their hospital. The mean score of affective commitment and continuance commitment was also moderate, meaning that nurses had a moderate level of both types of commitment. The mean score of normative commitment was low, which means that nurses had a low level of normative commitment. This means that the degree of staff nurses' commitment to their hospital is quite moderate.

In addition these results were inconsistent with Dorgham (2012) ${ }^{(51)}$ who found that the studied participants had low commitment toward their hospital, as they did not feel emotionally attached to their hospital or they felt that the hospital did not deserve their loyalty. Also El-Demerdash et al. (2013) ${ }^{(52)}$ reported in their study that three-fourths of staff nurses had a moderate level of total organizational commitment.

Also, these results were not consistent with Labrague et al (2018) ${ }^{(53)}$ who had a study on nurses working in nine hospitals in the rural areas at the Central Philippines; and revealed in their study, that nurses perceived "moderate commitment", with higher scores observed in the "affective commitment subscale."
The current study revealed that there were positive correlations between transformational leadership style with (transactional leadership style, leadership behavior, and with organizational commitment); also, there were positive correlations between transactional leadership style with (leadership behavior, and with organizational commitment. While no correlation between lassie-faire style and other styles as well as leadership behavior and organizational commitment. This may be due to the effective characteristics of transformational as well as transactional leadership style which positively improves head nurses leadership behaviors and thus in turn the staff nurses' organizational commitment will be improved.

These results were in line with Çokluk and Yılmaz (2010) ${ }^{(54)}$ who revealed that there was a moderate positive relationship between the teachers' perceptions about organizational commitment and supportive leadership behavior of school administrators. There was a moderate negative relationship between organizational commitment and directive leadership behavior of school administrators. Also, Anderson (2015) ${ }^{(55)}$ agreed with the current study results as he revealed there was a very strong correlation between transactional leadership and transformational leadership indicated (.89).

Furthermore, Garg and Ramjee (2013) ${ }^{(39)}$ displayed that the correlation results suggest that although the relationship is not strong, there is a positive relationship between the transformational leadership behaviors and commitment. This means that leadership behaviors, which involve building trust, inspiring a shared vision, encouraging creativity and emphasizing development, is somewhat positively related to employee commitment.

Also, Keskes (2014) ${ }^{(56)}$ mentioned that there is substantial evidence that transformational leadership is positively related to employee organizational commitment. This was demonstrated in numerous studies which have applied a direct effect approach to examine the effect of transformational leadership on organizational commitment. However, the mechanisms by which transformational leaders influence their followers have not been studied in a systematic manner

While, these results were not in same line with Lo et al. (2010) (57) who found none of the dimensions of transactional leadership styles were found to have significant impact on all three components of organizational commitment. Generally, the present study has exhibited that transformational leaders have a more significant and stronger relationship with organizational commitment. Also, this was not consistent with Walumbwa and Lawler (2003) ${ }^{(58)}$ who elucidated that leader who exhibit transformational leadership styles are more effective in achieving significantly higher commitment levels than transactional leaders

These results indicated that the head nurse who use transformational and transactional leadership styles as they provide more support, motivate their subordinates, provide more shared decision making, provide guidance, and more communicators; had more positive high score of leadership behaviors which have a direct effect on the their staff nurses commitment. This was in line with Lo et al. (2010) ${ }^{(57)}$ who mentioned that the leaders who give advice, support and pay attention to the individual needs of followers will enhance the level of organizational commitment of the employees 


\section{Conclusion}

It can be concluded from the current study that the highest percentage of the staff nurses perceived their head nurses had high level for transformational leadership style and its subscales, as well as had high level for transactional leadership style and its subscales; except the majority of the staff nurses perceived their head nurses had low level to lassie-faire style. Regarding the leadership behavior, the current study showed that the highest percentage staff nurses perceived their head nurses had high level to all dimensions of leadership behaviors; as well as it was noted that more than half of staff nurses perceived their head nurses had high level of leadership behaviors.

Moreover, near the half of staff nurses had moderate level regarding affective commitment; while more than two third had high level regarding continuance commitment and normative commitment. And it was noted that more than half had high level commitment, and more than one third $(41.2 \%)$ had moderate level.

Furthermore, there were positive correlations between transformational leadership style with (transactional leadership style, leadership behavior, and with organizational commitment); also, there were positive correlations between transactional leadership style with (leadership behavior, and with organizational commitment. While no correlation between lassie-faire style and other styles as well as leadership behavior and organizational commitment.

Recommendations: According to the results of the current study, the following recommendations are suggested:

* Emphasis on developing head nurses leadership skill using continuous learning program like small group discussion.

* There should be clear policy and regulations in organizational systems that will increase organizational commitments.

* The nurse managers and policy makers should improve nursing work conditions using the different strategies such as; reduce nurse workload through appropriate staffing, improve access to information, distribute resources fairly, provide professional development opportunities, and improve nurses' leadership skills such as decision making and empowerment.

\section{References:}

1. Bivins R, Tierney S, Seers K. Compassionate care: not easy, not free, not only nurses. Open Access. United Kingdom: Warwick Medical School, University of Warwick. 2017. Available at http://qualitysafety.bmj.com/

2. Graduate nursing. Nurse Administrator (leader). Available at https://www.graduatenursingedu.org/nurse-administrator/. Update (2017). Cited in 12/12/2017.

3. Sarwar KB, Khatun MR. Nursing administration and management. School of science and technology, Bangladesh Open University. 2007.

4. Day D, Fleenor J, Atwater L, Sturm R, McKee R. Advances in leader and leadership development: A review of 25 years of research and theory. The Leadership Quarterly. (2014); 25 (1): 6382.

5. Olu-Abiodun O, Abiodun O. Perception of transformational leadership behavior among general hospital nurses in Ogun State, Nigeria. International Journal of Africa Nursing Sciences. 2017; 6 (1): 22-7.

6. World Economic Forum. The Future of Jobs Employment, Skills and Workforce Strategy for the Fourth Industrial Revolution, Global Challenge Insight Report. 2016.

7. Courtney M, Nash R, Thornton R, Potgieter I. Leading and managing in nursing practice: Concepts, processes and challenges.
2015. In Daly J, Speedy D, Jackson D. Leadership \& Nursing contemporary perspectives. $2^{\text {nd }}$ ed. Australia: Elsevier Com., 2015.

8. Chung R.-G, Lo C.-L. The relationship between leadership behavior and organizational performance in non-profit organizations, using social welfare charity foundations as an example. Journal of American Academy of Business, Cambridge. 2007; 12: 83-7.

9. Bate JD, Johnston JE. Strategic frontiers: The starting point for innovative growth. Strategic and Leadership, 2005; 33(1): 12-8.

10. Japanese Nursing Association. Nursing in Japan. Available from: http://www.nurse.or.jp/jna/english/pdf/nursing-injapan2016.pdf [last accessed 27 Jun 2016].

11. Mosadeghrad AM. Principles of Health Care Administration. Dibagran Tehran, Tehran. $2003 \mathrm{~b}$.

12. Casida J, Parker J. Staff nurse perceptions of nurse manager leadership styles and outcomes. Journal of Nursing Management. 2011; 19 (4): 478-486.

13. Suhonen M. Paasivaara L. Shared human capital in project management: A systematic review of the literature. Project Management Journal. 2010; 42(2): 4-16.

14. Foon MS. A Conceptual Framework of Transformational and Transactional Leadership on Nurse Educators Job Satisfaction. International Journal of Social Science and Humanities Research, (2016). 4(1), 96-105.

15. Alshahrani FM, Baig LA. Effect of leadership styles on job satisfaction among critical care nurses in Aseer, Saudi Arabia. Journal of the College of physicians and Surgeons Pakistan, 2016; 26(5): 66-70.

16. Yahaya A, Osman I, Mohammed AB, Gibrilla I, Issah E. Assessing the effects of leadership styles on staff productivity in Tamale, Polytechnic, Ghana. International Journal of Economics, Commerce and Management, II, 9. 2014.

17. Khan MS, Khan I, Qureshi QA, Ismail HM, Rauf H, Latif A, Tahir M. The styles of leadership: A critical review. Public Policy and Administration Research, 2015; 5(3): 87-92.

18. Casida J, Parker J. Staff nurse perceptions of nurse manager leadership styles and outcomes. Journal of Nursing Management, 2011; 19(4): 78-86.

19. Oladipo KS, Jamilah O, Abudul-Daud S, Jeffrey LD, Salami DK. Review of leadership theories and organizational performances. International Business Management, 2013; 7(1): 5054.

20. Mitonga-Monga J, Coetzee M, Cilliers FV. Perceived leadership style and employee participation in a manufacturing company in the democratic republic of Congo. African journal of business management, 2012; 6(15): 89-98.

21. Alkahtani AH. The influence of leadership styles on organizationa commitment: The moderating effect of emotional intelligence. Business and Management Studies, 2015; 2(1), 23-34

22. Haghighy M, Shahrakimojahed L, Shahrakivahed A. Predicting Fars province Red Crescent staff and managers' Organizational Commitment based on their Emotional Intelligence and Organizational Culture. International Journal of Humanities and Cultural Studies (IJHCS) 2016; 3(1), 24-37.

23. Fabiene EE, Kachchhap SL. Determinants of employee's commitment among healthcare professionals. International Journal of Academic Research in Accounting, Finance and Management Sciences, 2016; 6(2), 44-52.

24. Manetje $\mathrm{O}$, Martins $\mathrm{N}$. The relationship between organizational culture and organizational commitment. Southern African Business Review, 2009; 13(1), 87-111

25. Kate W, Masako T. Reframing organizational commitment within a contemporary careers framework, Cornell University, New York, 2002.

26. Meyer JP, Stanley DJ, Herscovitch L, Topolnytsky L. Affective, continuance and normative commitment to the organization: A meta-analysis of antecedents, correlates and consequences. Journal of Vocational Behavior. 2002; 61: 20-52.

27. Smith M, Higgs J, Ellis E. Clinical Reasoning and Clinical Decision Making - Nature and Context. 3rd ed. Loftus S, editors. 2008Chapter 8: Factors influencing clinical decision making; pp: $89-100$.

28. Scott L, Caress A. Shared governance and shared leadership: Meeting the challenges of implementation. Journal of Nursing Management. 2005; 13(1): 4-12.

29. Kreitner R. Kinicki A. Organizational Behavior. 6th ed. New York: McGraw-Hill Com ; 2008.

30. Walumbwa FO, Orwa B, Wang P, Lawler JJ. Transformational leadership, organizational commitment, and job satisfaction: a comparative study of kenyan and U.S. financial firms. Human Resource Development Quarterly. 2005; 16(2):235-56.

Hend M., et al 
31. Chung, RG, Lo CL. The relationship between leadership behavior and organizational performance in non-profit organizations, using social welfare charity foundations as an example. Journal of American Academy of Business, 2007; 12(1): 83-87.

32. Ali KA, and Helal WE. Impact of the organizational design on the organizational behaviors of nurses among healthcare sectors. IOSR Journal of Nursing and Health Science (IOSR-JNHS), 2019; 8(6): 63-81.

33. Sepahvand F, Atashzadeh-Shoorideh F, Parvizy S, Tafreshi MZ. The relationship between some demographic characteristics and organizational commitment of nurses working in the Social Security Hospital of Khorramabad. Electron Physician 2017;9 (6):4503-9.

34. Cao J, Hamori M. The impact of management development practices on organizational commitment. Hum Resour Manag 2016; 55(3):499e517.

35. Zhou J, Plaisent M, Zheng L, Bernard P. Psychological contract, organizational commitment and work satisfaction: survey of researchers in Chinese state owned engineering research institutions. Open J Soc Sci 2014; 2(9):217-25.

36. Lo MC, Ramayah T, Min HW, Songan P. The relationship between leadership styles and organizational commitment in Malaysia: role of leader-member exchange. Asia Pacific Business Review, 2010; 16(1-2): 79-103.

37. Abdelhafiz IM, Alloubani AM, Almatari M. Impact of leadership styles adopted by head nurses on job satisfaction: a comparative study between governmental and private hospitals in Jordan. Journal of Nursing Management, 2016; 24: 384-392.

38. Ibrahim SA, El Sayed RI, Attala MM, Elmezin NK. Relationship between Head Nurses' Leadership Styles and Staff Nurses' Job Performance. IOSR Journal of Nursing and Science (IOSR-JNHS), 2016; 5(1): 66-74.

39. Garg AK, Ramjee D. The Relationship Between Leadership Styles And Employee Commitment At A Parastatal Company In South Africa. International Business \& Economics Research Journal, 2013; 12(11):1411-36.

40. Ahmed AK, Ata AA, Abd-Elhamid ZN. Relationship between the Leadership Behaviors, Organizational Climate, and Innovative Work Behavior among Nurses. American Journal of Nursing Research, 2019;7(5): 870-8.

41. Majeed N, Ramaya T, Mustamil N, Nazri M, Jamshed S. Transformational leadership and organizational citizenship behavior: Modeling emotional intelligence as mediator. Journal of Management and Marketing: Challenges for the Knowledge Society Journal, 2017; 12 (4): 571-90.

42. El-Demerdash SM, Aldeeb GA. Head nurses' transformational leadership, collaboration and its relation to staff nurses' work engagement, International Journal of Nursing Didactics, 2016; 6(7): $30-9$

43. Aboshaiqah AE, Hamdan-Mansour AM, Sherrod DR, Alkhaibary A, Alkhaibary S. Nurses' perception of managers' leadership styles and its associated outcomes. American Journal of Nursing Research, 2014; 2 (4): 57-62.

44. Olu-Abiodun O, Abiodun O. Perception of transformational leadership behaviour among general hospital nurses in Ogun State,
Nigeria. International Journal of Africa Nursing Sciences, 2017; 6: 22-7.

45. Lin P, MacLennan S, Hunt N, Cox T. The influences of nursing transformational leadership style on the quality of nurses' working lives in Taiwan: A cross-sectional quantitative study. BMC Nursing, 2015; 14(1): 14-33.

46. Dadgar H, Barahouei F, Mohammadi M, Ebrahimi M, Ganjali A. The relationship between organizational culture, job satisfaction, organizational commitment and intention to stay of health personnel's of Zahedan University of Medical Sciences. World Appl Sci J, 2013; 21:1220-1228.

47. Alammar K, Alamrani M, Alqahtani S, Ahmad M. Organizational Commitment and Nurses' Characteristics as Predictors of Job Involvement. Nursing Leadership, 2016; 29 (4): 59-69.

48. Abed F, Elguindy H. The relationship between organizational commitment and anticipated turnover among staff nurses in university hospital. Egypt J Health Care, 2014; 5:237-251.

49. Lorber M, Savic B. Factors affecting nurses' organizational commitment in Slovenian hospitals. Obzor Zdrav Neg, 2014; 48:294-301.

50. Ahmed RM, Abdelwahabb EA, Elguindy H. Staff nurses' intention to leave nursing profession and their organizational commitment in selected hospitals at Beni-Sueif city. Egyptian Nursing Journal, 2017; 14:17-24

51. Dorgham SR. Relationship between organization work climate and staff nurses organizational commitment. Nat Sci, 2012; 10:80-91.

52. El-Demerdash SM, Basal AA, Al-Deeb GA. The relationship between burnout and organizational commitment among nurses at Tanta University Hospital. J Nurs Health Sci, 2013; 2:20-28.

53. Labrague, LJ, McEnroe-Petitte DM, Tsaras K, Cruz JP, Colet PC, Gloe DS. Organizational commitment and turnover intention among rural nurses in the Philippines: Implications for nursing management. International Journal of Nursing Sciences, 2018; 5: 403- 8 .

54. Çokluk Ö, Yılmaz K. The Relationship between Leadership Behavior and Organizational Commitment in Turkish Primary Schools. Bilig - Turk DunyasI Sosyal Bilimler Dergisi, 2010; 54: 75-92

55. Anderson LE. Relationship between Leadership, Organizational Commitment, and Intent to Stay Among Junior Executives. Doctoral dissertation, College of Management and Technology, Walden University, 2015.

56. Keskes I. Relationship between leadership styles and dimensions of employee organizational commitment: A critical review and discussion of future directions. Intangible Capital, IC, 2014; 10(1): 26-51.

57. Lo MC, Ramayah T, Min HW, Songan P. The relationship between leadership styles and organizational commitment in Malaysia: role of leader-member exchange. Asia Pacific Business Review, 2010; 16(1-2): 79-103.

58. Walumbwa FO, Lawler JJ. Building effective organizations: transformational leadership, collectivist orientation, work-related attitudes, and withdrawal behaviors in three emerging economies. International journal of human resource management, 2003; 14, 1083-1101. 